\title{
Evaluation of the Effects of Anesthetic Agents and Diagnoses on Seizure Durations, Recovery Times and Complications in Electroconvulsive Therapy
}

\author{
Adnan Tufek', Mahmut Bulut², Orhan Tokgoz', Feyzi Celik', Zeynep Baysal Yildirim³ , Abdullah Atli², \\ Mehmet Cemal Kaya ${ }^{2}$, Haktan Karaman ${ }^{3}$
}

\section{ÖZET:}

Elektrokonvülsif terapide anestezik ajanların ve tanıların nöbet süreleri, derlenme süreleri ve komplikasyonlar üzerine olan etkilerinin değerlendirilmesi

Amaç: $\mathrm{Bu}$ çalışmada elektrokonvulzif terapi (EKT) anestezisinde kullanılan üç farklı anestezik ajanın ve tanıların nöbet süreleri, hemodinamik parametreler, derlenme süreleri ve yan etkiler üzerine olan etkilerinin retrospektif olarak değerlendirilmesi amaçlandı.

Yöntem: 1 Eylül 2009-30 Haziran 2012 tarihleri arasında Dicle Üniversitesi Psikiyatri Kliniğinde EKT endikasyonu konulan ve genel anestezi altında EKT uygulanan toplam 179 hastanın 1342 EKT seansı retrospektif olarak incelendi. EKT endikasyonları ve kullanılan anestezik ajanların, uygulanan EKT sayısı, motor ve EEG nöbet süreleri, anesteziden derlenme süreleri, hemodinamik değişiklikler ve komplikasyonlar ile ilişkisi analiz edildi.

Bulgular: Çalışmaya dahil edilen 179 hastanın yaş ortalaması $36.7 \pm 7.3$ yıl idi. \%50.8'i ( $n=91$ ) erkek, \%49.2'si $(n=88)$ kadındı. En çok kullanılan anestezik ajan propofol idi (\%73.2). Hastaların \%50.8 major depresyon, \%28.5'i bipolar bozukluk, \%12.8'i şizofreni tanısılla takip edilmekteydi. Uygulanan toplam 1342 EKT seansının 179'u (\%13.3) başarısız olarak kabul edildi. Başarısız EKT'lerin \%92.2'sinde propofol anestezisi kullanılmışı. Elektrokonvulzif terapi endikasyonu koyduran tanıların motor ve EEG nöbet süreleri, spontan solunum başlangıcl, göz açma, sözel uyaranlara yanıt verme süreleri, hemodinamik parametrelerdeki değişiklikler ve komplikasyonlar arasında istatistiksel olarak anlamlı ilişki saptanmadı. Propofol grubunda nöbet ve derlenme süreleri ketamin ve etomidat gruplarına göre anlamlı olarak daha kısaydı $(p<0.05)$. Etomidat grubunda ise EEG nöbet süreleri propofol ve ketamin grubuna göre daha uzundu (sırasıyla $p<0.001, p<0.05$ ).

Sonuç: Sonuç olarak motor ve EEG nöbet süreleri, spontan solunum başlangıcl, göz açma, sözel uyaranlara yanıt verme süreleri, hemodinamik parametrelerdeki değişiklikler ve komplikasyonlar üzerine tanıların bir etkisi bulunmamaktadır. Ancak kullanılan anestezik ajanlar tüm bu parametreleri etkilemektedirler.

Anahtar sözcükler: elektrokonvulzif terapi, propofol, etomidat, ketamin, majordepresyon, bipolar bozukluk, şizofreni

Klinik Psikofarmakoloji Bulteni 2014;24(1):23-30

\section{ABSTRACT:}

Evaluation of the effects of anesthetic agents and diagnoses on seizure durations, recovery times and complications in electroconvulsive therapy

Objective: The aim of this study is to retrospectively evaluate the influence of diagnosis and three different anesthetic agents on seizure durations, hemodynamic parameters, recovery times, and side effects in electroconvulsive therapy (ECT)

Method: We have retrospectively evaluated 1342 ECT sessions conducted on 179 patients under general anesthesia at the Psychiatry Department of Dicle University Hospital between 1 September 2009 and 30 June 2012. The relationship between the indications for ECT and the choice of anesthetic agent, number of ECT sessions, motor and EEG seizure durations, recovery times from anesthesia, hemodynamic changes and complications were analysed.

Results: The mean age of the 179 patients included in the study was $36.7 \pm 7.3$ years. In terms of sex, $50.8 \%$ $(n=91)$ were male and $49.2 \%(n=88)$ were female. The most commonly used anesthetic agent was propofol (73.2\%). Among the patients, $50.8 \%$ was diagnosed with major depression, $28.5 \%$ had bipolar disorder and $12.8 \%$ was diagnosed with schizophrenia. A total of 179 (13.3\%) out of the 1342 ECT sessions were considered as failed. In $92.2 \%$ of the failed ECTs, the anesthetic agent was propofol. No statistically significant relationship was observed between the diagnosis forming the basis for the $\mathrm{ECT}$ and the motor and EEG seizure times, beginning of spontaneous breathing, eye opening, time until response to verbal stimuli, changes in hemodynamic parameters and complications. The seizure and recovery times were significantly shorter in the propofol group compared to the ketamine and etomidate groups $(p<0.05)$. The EEG seizure durations were longer in the etomidate group in comparison to the propofol and ketamine groups $(p<0.001$ and $p<0.05$, respectively).

Conclusion: The diagnoses leading to the ECT have no influence on the motor and EEG seizure times, beginning of spontaneous breathing, eye opening, times of response to verbal stimuli, hemodynamic parameters or complications. However, the anesthetic agents used influence all of these parameters.

Keywords: electroconvulsive therapy, propofol, etomidate, ketamine, major depression, bipolar disorder, schizophrenia

Bulletin of Clinical Psychopharmacology 2014;24(1):23-30
'Assist. Prof., Dicle University School of Medicine, Department of Anesthesiology and Reanimation, Diyarbakir - Turkey ${ }^{2}$ Assist. Prof., Dicle University School of Medicine, Department of Psychiatry, Diyarbakir - Turkey

${ }^{3}$ Assoc. Prof., Dicle University School of Medicine, Department of Anesthesiology and Reanimation, Diyarbakir - Turkey

Address reprint requests to: Dr. Adnan Tüfek

Dicle Üniversitesi Hastanesi Anestezi Anabilim Dalı 21280

Diyarbakir - Turkey

E-mail address: adnantufek@hotmail.com

Date of submission: January 03, 2013

Date of acceptance: February 07, 2013

Declaration of interest:

A.T., M.B., O.T., F.C., Z.B.Y, A.A., M.C.K H.K.: The authors reported no conflict of interest related to this article. 


\section{INTRODUCTION}

Electroconvulsive therapy (ECT) is an efficient and life-saving method based on generating diverse convulsions through the electrical stimulation of the brain tissue. It is used in the case of psychiatric disorders such as major depression, catatonic schizophrenia, bipolar disorder or neuroleptic malignant syndrome where pharmacological treatment has not lead to satisfactory results ${ }^{1,2}$. Electroconvulsive therapy is applied 2 or 3 times a week for a total of 6 to 12 sessions depending on the clinical condition and the response. For an efficient treatment, the duration of the convulsions must be a minimum of 25 seconds ${ }^{3}$. In order to prevent any trauma, which may occur during the convulsions, ECT is carried out under general anesthesia ${ }^{4,5}$.

Since the general anesthetics have anticonvulsant properties, they reduce the duration of the convulsions depending on the dose and reduce the efficiency of the $\mathrm{ECT}^{2,6}$. Also, since the ECT is a procedure with a short duration, the anesthetic agents should induce a rapid anesthesia and lead to a rapid recovery ${ }^{1,6}$.

Electroconvulsive therapy may have certain side effects, some of which result from the ECT itself and others from the method of anesthesia. While the duration of the convulsions is related to the anesthetics and the stimulus required for the ECT, the length of the recovery period and side effects such as nausea or hemodynamic instability have been associated with the anesthetic agents administered during the procedure ${ }^{7}$. In the literature, there is no study focussing on the relationship between the anesthetic agents used during the ECT and the diagnosis, or the relationship between the diagnosis and the side effects.

Although methohexital, which is the gold standard for anesthesia in electroconvulsive therapy, is widely used around the world, it is not available in our country ${ }^{2}$. Due to its properties leading to a rapid recovery, propofol is the preferred hypnotic agent during ECT. However, propofol has a stronger anticonvulsant effect than the other intravenous (iv) anesthetics ${ }^{8}$. Etomidate is especially preferred in patients with short durations of convulsions in response to maximal electrical stimulants and generally leads to longer seizures ${ }^{2}$. Ketamine, an N-methyl D-aspartate (NMDA) receptor antagonist, has been reported to have antidepressant properties $^{9,10}$. However, it is less preferred in ECT since it raises the blood pressure and intracranial pressure, and leads to dissociative symptoms.

The aim of our study was to retrospectively compare the psychiatric diagnoses forming the basis of the ECT and the three anesthetic agents used during the procedure in our clinic in terms of their effects on seizure duration, hemodynamic parameters and recovery criteria.

\section{MATERIALS AND METHOD}

This study was conducted at the Dicle University Medical School between 1 September 2009 and 30 June 2012 subsequent to the approval of the Ethics Committee. The 1342 sessions performed on 179 patients, who had undergone electroconvulsive therapy were retrospectively evaluated. The patient files reflected that the written consent of the patients or their next of kin was obtained before the procedures. The files of the ECT patients were scanned and the patient demographics such as the age and sex, indications for the ECT, anesthetic agents used, the number of the ECTs applied, durations of the motor and EEG seizures, recovery times from the anesthesia, hemodynamic changes, and complications such as headache or nausea were recorded.

The retrospective scan of the patient files revealed that the ECTs were performed between 9:00 and 12:00 AM after a 12-hour fasting period and using the brief-pulsed, constant current Thymatron System IV (Somatics, LLC. Lake Bluff, IL, USA) ECT device and bitemporal electrodes. It was also observed that the ECTs were planned for an average of 6 sessions held twice weekly and the number of sessions was increased in patients 
where it was deemed necessary. The seizure threshold of the first ECT session was specified through the "stimulus dose titration" method".

All the patients were evaluated by an anesthesiologist before the ECT and an adequate fasting period was observed. All the ECTs were performed in the operating room of the Dicle University Medical School Hospital. The ECT team consisted of an anesthesiologist, anesthesia technician, supervising nurse and other medical personnel under the coordination of a psychiatrist. In all the patients admitted to the operating room, standard anesthetic monitoring was applied and the heart rate (HR), systolic arterial pressure (SAP), diastolic arterial pressure (DAP), mean arterial pressure (MAP) and peripheral oxygen saturation $\left(\mathrm{SpO}_{2}\right)$ (Datex Ohmeda S/5 Helsinki/ Finland) were recorded in addition to electroencephalography (EEG) (Thymartron System IV, Somatics, LLC. Lake Bluff, IL, USA).

Independently from the anesthetic agent, all the patients were pre-medicated with $0.5 \mathrm{mg}$ of atropine and inserted a bite block to protect the teeth before the procedure. The anesthesia was induced using propofol $(1 \mathrm{mg} / \mathrm{kg})$, etomidate $(0.1$ $\mathrm{mg} / \mathrm{kg})$ or ketamine $(1 \mathrm{mg} / \mathrm{kg})$ through the intravenous route. In order to better evaluate the motor seizures, an arm was isolated from the circulation through a tourniquet after the patient lost consciousness and $0.5 \mathrm{mg} / \mathrm{kg}$ of succinylcholine was administered to induce muscular relaxation. During the apneic period, patients breathed $100 \% \mathrm{O}_{2}$ through a face mask.

During routine ECTs, as the fasciculations due to succinylcholine subside, ECT is applied with a medium stimulation dose above the threshold (50$200 \%$ of the seizure threshold) and the seizures are monitored by recording the EEG. Seizures below 25 seconds are accepted as failed seizures during the ECT sessions. The duration of the motor and EEG seizures are measured based on the length of the contraction in the arm which had the tourniquet applied and the seizure time is recorded through the EEG. When an EEG seizure exceeds 90 seconds, it is accepted as a prolonged seizure and the patient is administered $2 \mathrm{mg}$ of iv midazolam. Also, when the convulsions recede, the patients' respiration is supported through the mask until the spontaneous respiration is adequate.

Patients were grouped according to anesthetic agents and diagnoses. The relationship of the demographic data, diagnoses and anesthetic agents with motor and EEG seizure durations, beginning of spontaneous breathing, eye opening, time until response to verbal stimuli, changes in hemodynamic parameters and complications were individually assessed.

The statistical analyses were carried out using the SPSS software. All the data were calculated as mean \pm standard deviation or percentage. The normality of the constant variables was tested through the Kolmogorov-Smirnov test. Data within a normal distribution were analysed using a parametric One-Way ANOVA, while those outside a normal distribution were analysed using the nonparametric Kruskal Wallis test. The paired comparisons of the data found to be different between the groups were carried out through the Post-Hoc Tukey test or the Bonferroni corrected Mann Whitney U-test. Categorical data were analysed using the Chi-square test. The change in the hemodynamic data was evaluated through the repeated measurements analysis of variance. Finally, the relationship between anesthetic agents and diagnoses was analysed with the help of Pearson's correlation analysis. Statistical significance was based on a value of $\mathrm{p}<0.05$.

\section{RESULTS}

The demographic data of the patients are presented in Table 1 . No statistically significant relationship was observed between the demographic data (sex and age) and the motor and EEG seizure durations, beginning of spontaneous breathing, eye opening, time until response to verbal stimuli, changes in hemodynamic parameters and complications $(\mathrm{p}>0.05)$.

The relationship of the diagnoses with the motor and EEG seizure durations, beginning of spontaneous breathing, eye opening, time until 


\begin{tabular}{|c|c|c|c|c|}
\hline & $\begin{array}{c}n=179 \\
\text { Mean } \pm \text { SD or } \\
n(\%)\end{array}$ & $\begin{array}{c}\text { Propofol } \\
\text { Mean } \pm \text { SD or } \\
n(\%)\end{array}$ & $\begin{array}{c}\text { Etomidate } \\
\text { Mean } \pm \text { SD or } \\
n(\%)\end{array}$ & $\begin{array}{c}\text { Ketamine } \\
\text { Mean } \pm \text { SD or } \\
n(\%)\end{array}$ \\
\hline \multicolumn{5}{|l|}{ Demographic data } \\
\hline \multirow[t]{2}{*}{ Sex (male/female) } & $91 / 88$ & $58 / 65$ & $24 / 18$ & $9 / 5$ \\
\hline & & 68.7 & 23.5 & 7.8 \\
\hline Age (years) & $36.7 \pm 7.3$ & $35.1 \pm 5.6$ & $38.3 \pm 6.1$ & $38.9 \pm 9.6$ \\
\hline \multicolumn{5}{|l|}{ ECT } \\
\hline Total number of the ECT sessions & 1342 & $982(73.2)$ & $278(20.7)$ & $82(6.1)$ \\
\hline Number of failed ECTs* & $179(13.3)$ & $165(16.8)$ & $11(3.9)$ & $3(3.7)$ \\
\hline Number of the prolonged seizures ${ }^{\dagger}$ & $14(1.04)$ & 1 & 9 & 4 \\
\hline \multicolumn{5}{|l|}{ Diagnoses } \\
\hline Major depression & $91(50.8)$ & 61 & 19 & 11 \\
\hline Bipolar depression & $51(28.5)$ & 37 & 11 & 3 \\
\hline Schizoaffective disorder & $23(12.8)$ & 16 & 7 & 0 \\
\hline Other diagnoses & $14(7.8)$ & 9 & 5 & 0 \\
\hline
\end{tabular}

*ECT session where the duration of the EEG seizure is less than 25 sec., $\mathrm{tECT}$ session where the duration of the EEG seizure is longer than 90 sec., SD: Standard Deviation.

Table 2: Distribution of the seizure durations, successful ECT sessions, recovery times and side effects according to the indications for the ECT

\begin{tabular}{|c|c|c|c|c|c|}
\hline & $\begin{array}{c}\text { Major Depression } \\
\text { Mean } \pm \text { SD or } \\
n(\%)\end{array}$ & $\begin{array}{c}\text { Bipolar Disorder } \\
\text { Mean } \pm \text { SD or } \\
n(\%)\end{array}$ & $\begin{array}{l}\text { Schizophrenia } \\
\text { Mean } \pm \text { SD or } \\
n(\%)\end{array}$ & $\begin{array}{c}\text { Other } \\
\text { Mean } \pm \text { SD or } \\
n(\%)\end{array}$ & $\mathbf{p}$ \\
\hline \multicolumn{6}{|l|}{ Duration of seizure } \\
\hline Duration of motor seizure(s) & $23.23 \pm 7.40$ & $23.03 \pm 7.30$ & $23.36 \pm 7.37$ & $22.83 \pm 7.28$ & 0.735 \\
\hline Duration of EEG seizure (s) & $39.40 \pm 17.31$ & $37.88 \pm 16.42$ & $40.22 \pm 17.95$ & $39.56 \pm 17.03$ & 0.526 \\
\hline Number of successful ECTs & $569(86.7)$ & $310(86.8)$ & 189 (85.9) & $95(87.2)$ & 0.794 \\
\hline \multicolumn{6}{|l|}{ Recovery periods } \\
\hline $\begin{array}{l}\text { Beginning of spontaneous } \\
\text { breathing (min) }\end{array}$ & $3.29 \pm 0.91$ & $3.20 \pm 0.87$ & $3.22 \pm 0.88$ & $3.25 \pm 0.88$ & 0.285 \\
\hline Eye opening (min) & $4.60 \pm 1.66$ & $4.65 \pm 1.67$ & $4.49 \pm 1.72$ & $4.72 \pm 2.14$ & 0.344 \\
\hline $\begin{array}{l}\text { Time until response to verbal } \\
\text { stimuli (min) }\end{array}$ & $7.70 \pm 3.00$ & $7.91 \pm 2.91$ & $7.68 \pm 2.93$ & $7.71 \pm 3.13$ & 0.430 \\
\hline \multicolumn{6}{|l|}{ Side effects } \\
\hline Nausea & $20(3)$ & $4(1.1)$ & $2(0.9)$ & $3(2.8)$ & 0.108 \\
\hline Headache & $69(10.5)$ & $30(8.4)$ & $17(7.7)$ & $14(12.8)$ & 0.334 \\
\hline Agitation after the ECT & $33(5)$ & $15(4.2)$ & $5(2.3)$ & $8(7.3)$ & 0.169 \\
\hline Hypertension & $33(5)$ & $9(2.5)$ & $7(3.2)$ & $3(2.8)$ & 0.190 \\
\hline SD: Standard deviation & & & & & \\
\hline
\end{tabular}

response to verbal stimuli, changes in hemodynamic parameters and complications are presented in Table 2.

The relationship of the anesthetic agents with motor and EEG seizure durations, beginning of spontaneous breathing, eye opening, time until response to verbal stimuli, changes in hemodynamic parameters and complications are presented in Table 3.

\section{DISCUSSION}

In our study, no relationship was observed between the sex and age parameters and the motor and EEG seizure durations or failed ECTs. Studies have pointed out that advanced age and male sex are factors raising the seizure threshold. In patients with a high seizure threshold, the dose of the stimulus is increased ${ }^{11-14}$. The lack of a relationship 


\begin{tabular}{|c|c|c|c|}
\hline & $\begin{array}{c}\text { Propofol } \\
\text { Mean } \pm \text { SD or } \\
n(\%)\end{array}$ & $\begin{array}{c}\text { Etomidate } \\
\text { Mean } \pm \text { SD or } \\
n(\%)\end{array}$ & $\begin{array}{c}\text { Ketamine } \\
\text { Mean } \pm \text { SD or } \\
n(\%)\end{array}$ \\
\hline \multicolumn{4}{|l|}{ Duration of seizure } \\
\hline Duration of motor seizure(s) & $22.38 \pm 7.22^{\mathrm{a}, \mathrm{b}}$ & $25.93 \pm 7.16$ & $27.74 \pm 7.06$ \\
\hline Duration of EEG seizure $(\mathrm{s})$ & $34.80 \pm 14.88^{\mathrm{a}, \mathrm{b}}$ & $54.50 \pm 15.86^{c}$ & $49.77 \pm 14.18$ \\
\hline Number of successful ECTs & $817(83.2)^{\mathrm{a}}$ & $267(96)$ & $79(96.3)$ \\
\hline \multicolumn{4}{|l|}{ Recovery periods } \\
\hline Beginning of spontaneous breathing (min) & $3.31 \pm 0.76^{\mathrm{c}, \mathrm{d}}$ & $3.13 \pm 1.14$ & $3.04 \pm 1.17$ \\
\hline Eye opening (min) & $4.34 \pm 1.33^{\mathrm{a}, \mathrm{b}}$ & $5.54 \pm 2.47$ & $5.99 \pm 1.52$ \\
\hline Time until response to verbal stimuli (min) & $7.25 \pm 2.50^{\mathrm{a}, \mathrm{b}}$ & $9.54 \pm 3.73^{b}$ & $11.18 \pm 3.85$ \\
\hline \multicolumn{4}{|l|}{ Side effects } \\
\hline Nausea & $2(0.2)^{a, b}$ & $18(6.5)^{b}$ & $9(11)$ \\
\hline Headache & $77(7.8)^{a, b}$ & $28(10.1)^{\mathrm{b}}$ & $25(30.5)$ \\
\hline Agitation after the ECT & $32(3.3)^{\mathrm{a}, \mathrm{b}}$ & $13(4.7)^{\mathrm{b}}$ & $16(19.5)$ \\
\hline Hypertension & $11(1.1)^{\mathrm{a}, \mathrm{b}}$ & $16(5.8)^{b}$ & $25(30.5)$ \\
\hline
\end{tabular}

between age, sex and seizure duration in our study may be related to the dose of the stimulus. Also, no significant relationship was observed between the sex and age parameters and the beginning of spontaneous breathing, eye opening, time until response to verbal stimuli, changes in hemodynamic parameters and complications. This result may be associated with the medication administered before and after the ECT procedure.

In the literature, studies on the success of seizures during ECT usually blame the dose of the stimulus and the anesthetics for failed seizures? They also discuss factors affecting the seizure threshold such as age, sex, and the position of the electrode $^{11-14}$. However, the relationship between the diagnoses and the duration of the seizures has not been discussed. In our study, no relationship was observed between the diagnoses and the duration or success of the seizures. Also, no relationship was found between the diagnoses and the beginning of spontaneous breathing, eye opening, time until response to verbal stimuli, changes in hemodynamic parameters and complications ( $p>0.05)$. These results demonstrate that the diagnoses do not have an influence on the duration and success of the seizures, recovery times and side effects during the ECT.
For a successful ECT, convulsions with a duration of 20-30 seconds should be induced. The energy dose in ECT is the most important factor influencing the duration of the seizure. While an energy dose lower than the seizure threshold leads to inadequate convulsions, energy doses much above the seizure threshold increase the cognitive side effects ${ }^{6}$. Independently from the energy dose applied, the anesthetic agents may raise the seizure threshold and shorten the duration of the seizure $^{2}$. Since the majority of the anesthetics used during electroconvulsive therapy have anticonvulsant properties, they reduce the duration of the convulsions induced by the ECT depending on the dose ${ }^{2}$. In our study, $13.3 \%$ (179 sessions) of the ECT sessions were found to have failed because the duration of the EEG seizures was inadequate. This ratio was statistically significantly higher in the propofol group compared to the etomidate and ketamine groups $(16.8 \%, 4 \%, 3.7 \%$, respectively). Thus, the anesthetic agent used during the ECT plays an important role in achieving an adequate duration of seizures.

The ideal hypnotic agent to be used for the anesthesia during electroconvulsive therapy should have a short half life, should not influence the duration and quality of the seizures and 
should not disrupt the hemodynamic balance ${ }^{6}$. Propofol, which is a hypnotic agent that exerts its effect on GABA receptors, is widely used thanks to the rapid onset of its effect and short recovery time. Also, it is known that propofol more actively suppresses the hemodynamic response and intracranial pressure and does not affect cognitive function. However, propofol is also the hypnotic agent with the strongest anticonvulsant effect among the intravenous anesthetics used during ECT and thus raises the seizure threshold and reduces the duration of the seizure induced ${ }^{15}$. Also in our study, propofol was used in $92.2 \%$ of the 179 ECT sessions accepted as failed due to the shortness of the seizure duration. Although methohexital, which is a barbiturate with a short effect, is the gold standard for anesthesia in ECT and is widely used around the world, it is not available in our country. Therefore, we most commonly (73.2\%) prefer propofol during the ECT sessions in our centre.

Etomidate is an intravenous anesthetic with a rapid onset of effect and rapid metabolism. It has also been reported to have a minimal effect on the seizure threshold induced by ECT ${ }^{16}$. In comparison to methohexital, thiopental and propofol, etomidate enables the longest convulsions ${ }^{2}$, and it may be preferred in patients with short durations of convulsions in response to the highest electrical stimulation ${ }^{17}$. However, it cannot suppress the cardiovascular response as effectively as barbiturates or propofol. It also has limited use during ECT due to reports of adrenocortical suppression when infused in higher doses ${ }^{18,19}$. In our study, etomidate was preferred during 278 (20.7\%) ECT sessions in 42 patients $(23.4 \%)$ and only $3.9 \%(n=11)$ of the ECTs with etomidate were observed to have failed. Also, in 78 (43.5\%) out of the 179 ECTs which were accepted as failed, the treatment was continued with etomidate. In 72 ECT sessions in these patients who were switched to etomidate, the duration of EEG seizures was observed to increase over 40 seconds. In light of these data and the literature, in patients where an inadequate duration of seizures is observed with the previous anesthetic agent, the sessions may be continued with etomidate (unless there is another contraindication).

In a study where the effects of methohexital, propofol and etomidate were compared, the EEG and motor seizure durations were observed to be the longest in the etomidate group and the shortest in the propofol group. Especially, propofol doses over $2 \mathrm{mg} / \mathrm{kg}$ were reported to significantly reduce the seizure duration induced by $\mathrm{ECT}^{20}$. Also in our study, the durations of the motor and EEG seizures were observed to be shorter with propofol (Table 3).

Propofol has also been reported to be superior to etomidate in the control of the hemodynamic responses observed during electroconvulsive therapy ${ }^{21}$. However, in our study, propofol and etomidate were observed to be similar in terms of control of the hypertensive response to ECT. Still, since our study was not randomized, the uneven number of the patients and sessions in both groups may have affected the results.

Experimental studies have shown that NMDA receptor antagonists might have anxiolytic and anti-depressant properties ${ }^{22,23}$. Ketamine, which is an NMDA receptor antagonist, has been reported to have anti-depressant effects in humans ${ }^{9,10}$. During ECT performed on patients with major depression, ketamine was reported not to have any anti-depressant properties at a $0.5 \mathrm{mg} / \mathrm{kg} \operatorname{dose}^{24,25}$, while the $0.8 \mathrm{mg} / \mathrm{kg}$ dose showed anti-depressant activity $^{26}$. In a recent study where anesthesia with propofol, ketamine $(0.8 \mathrm{mg} / \mathrm{kg})$ and propofol+ketamine were compared during ECT sessions conducted due major depression, the Hamilton depression scores were found to have significantly increased in the ketamine groups in comparison to the use of propofol as a single agent $^{27}$. However, the properties of ketamine stimulating the sympathetic system and significantly increasing the systemic blood pressure and intracranial pressure limit its use during $\mathrm{ECT}^{2,28}$. Therefore, in our study, we have preferred anesthesia with ketamine especially in patients with treatment-resistant major depression and without any comorbidities. Since we did not evaluate the efficiency of the ECT applied in our 
study, we could not focus on the effects of ketamine in depression.

When the effects of anesthesia with etomidate or propofol on the recovery times after ECT are evaluated, propofol has been reported to have a better recovery profile ${ }^{16}$. In our study, the times until the beginning of spontaneous breathing, eye opening and following orders have been found to be significantly shorter in the propofol group compared to the etomidate and ketamine groups (Table 3 ). Times until the beginning of spontaneous breathing and eye opening were comparable in the etomidate and ketamine groups (Table 3). The time until following orders was longer in the ketamine group than in the other two groups (Table 3).

Mortality and serious morbidity are rarely observed in electroconvulsive therapy and the performance of ECT under general anesthesia has increased the safety of the procedure and reduced the side effects ${ }^{29,30}$. The most important morbidity involves transient memory loss, agitation and confusion, which usually spontaneously return to normal. The most frequently observed side effects are headache, muscle pain, nausea, fatigue and loss of appetite ${ }^{4}$. Studies have revealed the frequency of post-ECT headache to be between $26 \%$ and $85 \%^{31}$. The headache has an impact on the patient's compliance to the ECT and may lead to the interruption of the treatment ${ }^{32}$. In our study, the most frequently observed complaint was headache with a $9.6 \%$ frequency and it was most commonly observed in the patients in the ketamine group (Table 3). Agitation observed after ECT has been reported to be significantly greater with ketamine ${ }^{27}$. In line with the literature, post-ECT agitation also most commonly occurred in the ketamine group (19.5\%).

It is a known fact that the electrical current applied during the electroconvulsive therapy stimulates the sympathetic nervous system and increases the release of catecholamines from the adrenal medulla, leading to hemodynamic changes $^{33}$. Among the anesthetic agents, ketamine is especially associated with greater hemodynamic response $^{28}$. In our study, while the hemodynamic changes that occurred due to ECT in the propofol and etomidate groups were similar, blood pressure and heart rate were observed to increase significantly in the ketamine group. Therefore, it may be more appropriate to use ketamine in selected patients.

The fact that the effects of ECT and the anesthetics used during ECT on the treatment of the psychiatric disorders, and the effects of the medications used by the patients on the success of the ECT were not evaluated constitutes a limitation of our study. The retrospective design is another limitation.

In conclusion, it was observed that the pathologies of the patients, who underwent ECT did not affect the durations of the seizures or the management of the anesthesia. In patients where the anesthetic agents used lead to inadequate seizure durations, propofol and ketamine should be replaced with etomidate in the following ECT sessions. There is a need for randomised and controlled studies, where these three anesthetic agents are compared in terms of the success of ECT.

\section{References:}

1. Geretsegger C, Nickel M, Judendorfer B, Rochowanski E, Novak E, Aichhorn W. Propofol and methohexital as anesthetic agents for electroconvulsive therapy: a randomised, double-blind comparison of electroconvulsive therapy seizure quality, therapeutic efficacy, and cognitive performance. J ECT 2007;23(4):239-43. [CrossRef]

2. Ding Z, White PF. Anesthesia for electroconvulsive therapy. Anesth Analg 2002;94(5):1351-64. [CrossRef]

3. Smith DL, Angst MS, Brock-Utne JG, DeBattista C. Seizure duration with remifentanil/methohexital vs. methohexital alone in middle-aged patients undergoing electroconvulsive therapy. Acta Anaesthesiol Scand 2003;47(9):1064-6. [CrossRef]

4. Simpson KH, Lynch L. Anaesthesia and electroconvulsive therapy (ECT). Anaesthesia 1998;53(7):615-7. [CrossRef] 
5. Basgul E, Celiker V. Anaesthesia in electroconvulsive therapy. Turk Psikiyatri Derg 2004;15(3):225-35.

6. Folk JW, Kellner $\mathrm{CH}$, Beale MD, Conroy JM, Duc TA. Anesthesia for electroconvulsive therapy: a review. J ECT 2000;16(2):157-70. [CrossRef]

7. Hooten WM, Rasmussen KG, Jr. Effects of general anesthetic agents in adults receiving electroconvulsive therapy: a systematic review. J ECT 2008;24(3):208-23. [CrossRef]

8. Bailine SH, Petrides G, Doft M, Lui G. Indications for the use of propofol in electroconvulsive therapy. J ECT 2003;19(3):129-32. [CrossRef]

9. Berman RM, Cappiello A, Anand A, Oren DA, Heninger GR, Charney DS, et al. Antidepressant effects of ketamine in depressed patients. Biol Psychiatry 2000;47(4):351-4. [CrossRef]

10. Zarate CA, Jr., Singh JB, Carlson PJ, Brutsche NE, Ameli $\mathrm{R}$, Luckenbaugh DA, et al. A randomized trial of an $\mathrm{N}$-methyl-D-aspartate antagonist in treatment-resistant major depression. Arch Gen Psychiatry 2006;63(8):856-64. [CrossRef]

11. Chung KF. Determinants of seizure threshold of electroconvulsive therapy in Chinese. J ECT 2006;22(2):1002. [CrossRef]

12. Colenda CC, McCall WV. A statistical model predicting the seizure threshold for right unilateral ECT in 106 patients. Convuls Ther 1996;12(1):3-12.

13. McCall WV, Shelp FE, Weiner RD, Austin S, Norris J. Convulsive threshold differences in right unilateral and bilateral ECT. Biol Psychiatry 1993;34(9):606-11. [CrossRef]

14. Sackeim HA, Devanand DP, Prudic J. Stimulus intensity, seizure threshold, and seizure duration: impact on the efficacy and safety of electroconvulsive therapy. The Psychiatric clinics of North America 1991;14(4):803-43.

15. Fredman B, d'Etienne J, Smith I, Husain MM, White PF. Anesthesia for electroconvulsive therapy: effects of propofol and methohexital on seizure activity and recovery. Anesth Analg 1994;79(1):75-9. [CrossRef]

16. Rosa MA, Rosa MO, Belegarde IM, Bueno CR, Fregni F. Recovery after ECT: comparison of propofol, Etomidate and thiopental. Rev Bras Psiquiatr 2008;30(2):149-51. [CrossRef]

17. Conca A, Germann R, Konig P. Etomidate vs. thiopentone in electroconvulsive therapy. An interdisciplinary challenge for anesthesiology and psychiatry. Pharmacopsychiatry 2003;36(3):94-7. [CrossRef]

18. Khalid N, Atkins M, Kirov G. The effects of Etomidate on seizure duration and electrical stimulus dose in seizureresistant patients during electroconvulsive therapy. J ECT 2006;22(3):184-8. [CrossRef]

19. Celebioglu B, Yigit H, Rezaki M, Ercelen O, Kayatekin S. Anesthesia in electroconvulsive therapy. Ann Saudi Med 1999;19(2):144-6.
20. Avramov MN, Husain MM, White PF. The comparative effects of methohexital, propofol, and Etomidate for electroconvulsive therapy. Anesth Analg 1995;81(3):596-602.

21. Erdil F, Demirbilek S, Begec Z, Ozturk E, Ersoy MO. Effects of propofol or Etomidate on QT interval during electroconvulsive therapy. JECT 2009;25(3):174-7. [CrossRef]

22. Aguado L, San Antonio A, Perez L, del Valle R, Gomez J. Effects of the NMDA receptor antagonist ketamine on flavor memory: conditioned aversion, latent inhibition, and habituation of neophobia. Behav Neural Biol 1994;61(3):27181. [CrossRef]

23. Yilmaz A, Schulz D, Aksoy A, Canbeyli R. Prolonged effect of an anesthetic dose of ketamine on behavioral despair. Pharmacol Biochem Behav 2002;71(1-2):341-4. [CrossRef]

24. Loo CK, Katalinic N, Garfield JB, Sainsbury K, Hadzi-Pavlovic D, Mac-Pherson R. Neuropsychological and mood effects of ketamine in electroconvulsive therapy: A randomised controlled trial. J Affect Disord 2012;142(1-3):233-40. [CrossRef]

25. Abdallah CG, Fasula M, Kelmendi B, Sanacora G, Ostroff R. Rapid antidepressant effect of ketamine in the electroconvulsive therapy setting. J ECT 2012;28(3):157-61. [CrossRef]

26. Okamoto N, Nakai T, Sakamoto K, Nagafusa Y, Higuchi T, Nishikawa T. Rapid antidepressant effect of ketamine anesthesia during electroconvulsive therapy of treatmentresistant depression: comparing ketamine and propofol anesthesia. J ECT 2010;26(3):223-7. [CrossRef]

27. Wang X, Chen Y, Zhou X, Liu F, Zhang T, Zhang C. Effects of propofol and ketamine as combined anesthesia for electroconvulsive therapy in patients with depressive disorder. J ECT 2012;28(2):128-32. [CrossRef]

28. Rasmussen KG, Jarvis MR, Zorumski CF. Ketamine anesthesia in electroconvulsive therapy. Convuls Ther 1996;12(4):21723.

29. Weiner RD. Convulsive therapy: 50 years later. Am J Psychiatry 1984;141(9):1078-9.

30. Gaines GY $3^{\text {rd }}$, Rees DI. Anesthetic considerations for electroconvulsive therapy. South Med J 1992;85(5):469-82. [CrossRef]

31. Kramer BA, Kadar AG, Clark K. Use of the Neuro-Wrap system for severe post-electroconvulsive therapy headaches. J ECT 2008;24(2):152-5. [CrossRef]

32. Leung M, Hollander Y, Brown GR. Pretreatment with ibuprofen to prevent electroconvulsive therapy-induced headache. J Clin Psychiatry 2003;64(5):551-3. [CrossRef]

33. Weinger MB, Partridge BL, Hauger R, Mirow A, Brown $M$. Prevention of the cardiovascular and neuroendocrine response to electroconvulsive therapy: II. Effects of pretreatment regimens on catecholamines, ACTH, vasopressin, and cortisol. Anesth Analg 1991;73(5):563-9. [CrossRef] 